publication of a new natural history magazine, Loris, to be issued twice a year (Colombo and London : Times of Ceylon Co., Ltd. 2s. 6d.). That there is need for such propaganda is shown by the history of faunal protection in Ceylon, which A. B. Lushington contributes to the first number. The slaughter of sambhur and deer for the sake of the export of their hides and horns had reached gigantic proportions and entailed great cruelty, before the Government in $\mathbf{1 8 9 1}$ passed ordinances to check the trade and to "prevent the wanton destruction of elephants, buffaloes and other game". Even so the trade continued, and several subsequent enactments have been required to bring about the protection which was desired. The first number of Loris is by no means confined to direct propaganda, for the editors are aware that the stimulation of interest in animal life is a better means to their end than mere denunciation. Accordingly they include sporting articles of a naturalist flavour, accounts of trips in the jungle, and an instructive article on natural history photography and the apparatus it demands, illustrated by excellent photographs of birds and nests.

\section{Fisheries of Wales}

A TEMPORARY exhibition illustrating the activities of the Welsh fishing industry has been on view during the past five months at the National Museum of Wales. A small hand-book supplements the information given on the labels of the exhibits ("The Fisheries of Wales". By Colin Matheson. National Museum of Wales and the Press Board of the University of Wales. 2d.). The fishes landed in the largest quantities in Wales are demonstrated by models and spirit specimens, and the handbook sets forth the habitats and means of capture of the different species, with some comments on their biology. The hake, on which the deep-sea fisheries of South Wales are based, is given due prominence. A separate section is given to the deep-water trawler and its methods of work, with exhibits of echo-sounding devices and wireless direction-finders. The beam trawl and various appliances of the inshore fisherman are explained; and there are notes upon the primitive Welsh coracle and the salmon nets and spears used in fresh water. The general ignorance about the modern fishing industry is so great that a welcome must be extended to such an exhibition as this, for it will show that each species of fish must be sought by methods adapted to its habitat and habits; and that every fishing boat more than 20 feet long is not necessarily a trawler. Mr. Matheson is to be congratulated upon the arrangement of such a demonstration.

\section{British Association Seismological Committee}

THE recent report of the Committee of Seismological Investigations records much useful work done by its members. During the preceding year, three slight earthquakes occurred in the British Isles: in East Kent on December 29, 1936, in North Staffordshire on April 7, 1937, and near Inverness on June 26, 1937. Brief references are made to the study of the recent earthquakes in Montserrat, to Mr. Brennan's work on the greater frequency of earthquakes in Jamaica during the dry months of the year, to the deep-focus earthquakes of 1932, and to the new globe, 18 in. in diameter, recently installed at Oxford, which has already proved most useful in the determination of epicentres. Notes are also contributed by Dr. H. Jeffreys on seismic transmission times, and by Dr. R. Stoneley on his study of the records of the Mongolian earthquake of August 10, 1931.

\section{Parliamentary Science Committee}

The Right Hon. J. Ramsay MacDonald has recently accepted an invitation to join the executive of the Parliamentary Science Committee. It has always been the aim of the Committee to preserve an even balance between men of science and Parliamentarians on the executive, and on the Parliamentary side to secure representatives from all political parties. Mr. MacDonald's advent brings the Parliamentarians up to eleven-three peers, and eight members of the House of Commons. The three peers are the Earl of Dudley (president), Lord Melchett and Lord Rothschild. The members of the lower house are Sir Arnold Wilson (chairman), Mr. Alan Chorlton (deputy-chairman), Mr. Ramsay MacDonald, Prof. J. Graham Kerr, Sir Philip Dawson, Sir Murdoch MacDonald, Mr. Andrew MacLaren, and Mr. S. F. Markham.

\section{Komodo 'Dragons' at Edinburgh Zoological Park}

BY permission of the Netherlands Government, two Komodo monitors (Varanus komodoensis) have been added to the collections at the Scottish National Zoological Park in Edinburgh. This gigantic lizard, which may reach a length of 10 feet, was first shown in Great Britain at the London Zoo in 1927, a year after the habits of the creature had been studied by an American expedition in its native island of Komodo to the south-east of Java. It is swift and active out of keeping with its heavy build, and is said to be fierce as well as voracious, the larger individuals feeding when opportunity offers upon deer and wild pigs.

\section{The Joint Committee on Materials and Their Testing}

THE Joint Committee, whic consists of representatives of twenty-four co-operating technical institutions and societies under the chairmanship of Dr. H. J. Gough, has arranged its first technical discussion to take place in the College of Technology, Manchester, on October 29, commencing at 2.30 p.m., when a series of three important papers on different aspects of "Notched Bar Impact Testing" will be presented. Application forms for papers and reprints, and for tickets to attend, should be made to the Secretary, the Manchester Association of Engineers, St. John Street Chambers, Deansgate, Manchester, 3. Particulars regarding the objects, aims and work of the Joint Committee may be obtained from the Secretary, Joint Committee on Materials and their Testing, at the Institution of Mechanical Engineers, Storey's Gate, Westminster, London, S.W.1. 